\title{
Effect of Phosphorus and Biofertilizers on Growth and Yield of Mungbean [Vigna radiata (L.) Wilczek]
}

\section{Ch. Vidhyashree Venkatarao ${ }^{1 *}$, S.R. Naga ${ }^{2}$, B.L. Yadav $^{3}$, Deepak Kumar Koli ${ }^{4}$ and I. Jagga Rao}

${ }^{1}$ Department of Soil Science and Agricultural Chemistry, Agricultural College, Bapatla-522101, India

${ }^{2}$ Department of Soil Science and Agricultural Chemistry, S.K.N.A.U., Jobner-303329, India

${ }^{3}$ Sri Karan Narendra Agricultural University, jobner-303329, India

${ }^{4}$ Division of Microbiology, ICAR-Indian Agricultural Research Institute,

New Delhi-110012, India

*Corresponding author

\section{A B S T R A C T}

Keywords

Mungbean, Phosphorus, PSB, Aspergillus awamori.

Article Info

Accepted:

29 June 2017

Available Online:

10 July 2017
A field experiment was conducted during kharif season of 2015 on loamy sand soil at the Agronomy farm, S.K.N. College of Agriculture, Jobner (Rajasthan). The experiment consisted of four levels of phosphorus (Control, 20, 40 and $60 \mathrm{~kg}$ P2O5 $\mathrm{ha}^{-1}$ ) and four treatments of biofertilizers (Control, PSB, Aspergillus awamori and PSB + Aspergillus awamori) thereby, making sixteen treatment combinations and replicated thrice. The results indicated that application of phosphorus upto $40 \mathrm{~kg} \mathrm{P}_{2} \mathrm{O}_{5} \mathrm{ha}^{-1}$ recorded the highest number of total and effective number of nodules per plant, plant height, leaf area index, total chlorophyll content, grain yield $\left(1221 \mathrm{~kg} \mathrm{ha}^{-1}\right)$ and straw yield $\left(2988 \mathrm{~kg} \mathrm{ha}^{-1}\right)$ which was at par with $60 \mathrm{~kg} \mathrm{P}_{2} \mathrm{O}_{5} \mathrm{ha}^{-1}$. Results further indicated that seed inoculation with the PSB and Aspergillus awamori significantly increased highest number of total and effective number of nodules per plant, plant height, leaf area index, total chlorophyll content, grain yield $\left(1260 \mathrm{~kg} \mathrm{ha}^{-1}\right)$ and straw yield (3140 $\mathrm{kg} \mathrm{ha}^{-1}$ ) over the rest of the treatments. The seed inoculation with PSB and Aspergillus awamori individually remained at par.

\section{Introduction}

Pulses are important source of dietary protein and have unique ability of maintaining and restoring soil fertility through biological nitrogen fixation as well as addition of ample amount of residues to the soil. Pulse crops leave behind reasonable quantity of nitrogen in soil to the extent of $30 \mathrm{~kg} \mathrm{ha}^{-1}$. Mungbean [Vigna radiata (L.)Wilczek] is one of the important pulse crop grown in arid and semiarid regions in India. It is a short duration pulse crop which can be grown as catch crop during kharif and rabi seasons.

Phosphorus is an important nutrient next to nitrogen. At present $5 \%$ of the Indian soils have adequate available phosphorus? 
According to Motsara (2002), fertility status of Indian soils as compiled from the soil testing laboratories database are: $42 \%$ are under low category, $38 \%$ under medium and $20 \%$ under high category. The US Geological Survey, in 2006 estimated world Phosphatic Rock reserves are at about 18000 miliontonnes, whereas $\mathrm{P}$ resources are at about 50,000 million tonnes. Thus with this current level of $\mathrm{P}$ reserves, resources could last for 105 to 470 years and we have to utilize this resources effectively.

Only $25 \%$ to $30 \%$ of the applied $\mathrm{P}$ is available to crops and remaining $\mathrm{P}$ is converted into insoluble P (Sharma and Khurana, 1997). Its deficiency is the most important single factor, which is responsible for poor yield of mungbean on all types of soil. It is indispensable constituent of nucleic acids, ADP and ATP. It has beneficial effects on nodule stimulation, root development and growth and also hastens maturity as well as improves quality of crop produce. Thus, the response of $\mathrm{P}$ to legumes is more important than $\mathrm{N}$ as later is being fixed by symbiosis with Rhizobium bacteria.

Biofertilizers, a component of integrated nutrient management and are considered to be cost effective, eco-friendly and renewable source of non-bulky, low cost plant nutrient supplementing fertilizers in sustainable agriculture system in India. Therefore, the role of biofertilizers assumes a special significance in present context of very high costs of chemical fertilizers. The seed of pulses are inoculated with Phosphorus solublizers with an objective of increasing their number in the rhizosphere and substantial increase in the $\mathrm{P}$ availability for the plant growth.

Phosphorus solubilizing microorganisms (bacteria and fungi) enable $\mathrm{P}$ to become available for plant uptake after solubilization. Several soil bacteria, particularly those belonging to the genera Bacillus and Pseudomonas, and fungi belonging to the genera Aspergillus and Penicillium possess the ability to bring insoluble phosphates in soil into soluble forms by secreting organic acids such as formic, acetic, propionic, lactic, glycolic, fumaric, and succinic acids. These acids lower the $\mathrm{pH}$ and bring about the dissolution of bound forms of phosphates. Some of the hydroxyl acids may chelate with calcium and iron resulting in effective solubilisation and utilization of phosphates. The phosphate solubilizing microorganisms improved phosphorus uptake over control with and without chemical fertilizers.

\section{Materials and Methods}

A field experiment was conducted during kharifseason of 2015 at the Agronomy farm, S.K.N. College of Agriculture, Jobner (Rajasthan) in randomized block design with three replications. The soil was loamy sand in texture, alkaline in reaction $(\mathrm{pH} \mathrm{8.2),} \mathrm{low} \mathrm{in}$ organic carbon $\left(1.9 \mathrm{~g} \mathrm{~kg}^{-1}\right)$, available nitrogen $\left(130.10 \mathrm{~kg} \mathrm{ha}^{-1}\right)$, medium in available phosphorus (15.87 kg ha $\mathrm{kg}^{-1}$ ) and in available potassium $\left(140.02 \mathrm{~kg} \mathrm{ha}^{-1}\right)$ content.

The experiment consisted of four levels of phosphorus (Control, 20, 40 and $60 \mathrm{~kg}$ P2O5 $\mathrm{ha}^{-1}$ ) and four treatments of biofertilizers (Control, PSB, Aspergillus awamori and PSB + Aspergillus awamori) thereby, making sixteen treatment combinations. The mungbean var. RMG-492 sown on 18th July, 2015 using seed rate $20 \mathrm{~kg} \mathrm{ha}^{-1}$ with a row spacing of $30 \mathrm{~cm}$.

The crop was harvested on 8th October, 2015. As per treatments, seed were inoculated with $\mathrm{PSB}$, Aspergillus awamoria nd PSB + Aspergillus awamori before sowing using standard method and dried shade(Paul et al., 1971). Thinning was carried out at 10-20 DAS.A uniform basal dose of $25 \mathrm{~kg} \mathrm{~N}^{-1}$ was applied through DAP and urea to the soil. 
Urea was used to make up thequantity of $\mathrm{N}$ to $25 \mathrm{~kg} \mathrm{ha}^{-1}$ in addition to $\mathrm{N}$ supplied through DAP.

However, in control plots whole $\mathrm{N}$ was applied onlythrough urea. The phosphorus was applied through DAPas per the treatment details. The yield attributes and yieldwere recorded as per standard statistical procedures. Theobservation on growth parameters viz., the total and effective number of nodules per plant, plant height, leaf area index, total chlorophyll content, grain and straw yield $\left(\mathrm{kg} \mathrm{ha} \mathrm{ha}^{-1}\right)$ were analyzed byadopting standard procedures.

\section{Results and Discussion}

\section{Effect of phosphorus}

Application of graded levels of phosphorus upto $40 \mathrm{~kg}$ P2O5 ha ${ }^{-1}$ significantly increased the total and effective number of nodules per plant, plant height, leaf area index, total chlorophyll content, grain yield and straw yield.

However, the treatment P3 and P2 were statistically at par. This increase in growth parameters and yield might be due to phosphorus which is an indispensable, constituent of nucleic acid, ADP and ATP.

It has beneficial effects on nodulation, root development, growth and also hastens maturity as well as improves quality of crop produce (Choudhary et al., 2015). Such increase in nodulation, root and growth might be due to increase in number of nodules which might have supplied sufficient nitrogen by nitrogen fixation and finally enhance productivity of green gram (Prasad et al., 2014).

Besides, improvement in nodulation, the larger canopy development under the influence of increased $\mathrm{P}$ levels seems to have increased absorption and utilization of radiant energy resulting in higher effective and total nodules (Escalante et al., 2014). The rate of $\mathrm{P}$ absorption and translocation to the leaves may be an important factor to increase $\mathrm{N}_{2}$-fixation.

When $\mathrm{P}$ supply is limited, the availability of $\mathrm{P}$ and $\mathrm{N}$ to chloroplast became limited ultimately affect the photosynthetic processes as well as photosynthate supply to nodules. The effect of $\mathrm{P}$ could be related to the finding by that it stimulates root growth and activity and nodule formation (Escalante et al., 2014).

Phosphorus encourage formation of new cells, promote plant vigour and hastens leaf development, which help in harvesting more solar energy and better utilization of nitrogen, which help towards higher growth attributes. These findings are found relevant to Malik et al., (2003), Escalante et al., (2014), Rathour et al., (2015).

As a component of ATP, phosphorus is needed for the conversion of light energy to chemical energy (ATP) during photosynthesis. Phosphorus is also involved in better root growth enhanced nutrient uptake and translocation of photosynthates from source to sink.

The regulatory functions of phosphorus in photosynthesis and carbohydrates metabolism of leaves can be considered to be one of the major factors limiting plant growth particularly during the reproductive phase.

The level of phosphorus during this period regulates starch/sucrose ratio in the sources and the reproductive organs (Giaqinta and Quebedeaux, 1980). The improvement in yield is attributed to increase in root nodulation due to phosphorus application (Bhatt et al., 2013). 
Table.1 Plant growth parameters and yield of mungbean as influenced by Phosphorus and biofertilizers

\begin{tabular}{|c|c|c|c|c|c|c|c|}
\hline Treatments & $\begin{array}{c}\text { Total } \\
\text { Nodules }\end{array}$ & $\begin{array}{l}\text { Effective } \\
\text { nodules }\end{array}$ & $\begin{array}{c}\text { Plant } \\
\text { height } \\
\text { (cm) }\end{array}$ & $\begin{array}{l}\text { Leaf } \\
\text { area } \\
\text { index }\end{array}$ & $\begin{array}{c}\text { Total } \\
\text { chlorophyll } \\
\text { content } \\
\left(\mathbf{m g ~ g}^{-1}\right)\end{array}$ & $\begin{array}{c}\text { Grain } \\
\text { Yield } \\
\left(\mathbf{k g ~ h a}^{-1}\right)\end{array}$ & $\begin{array}{c}\text { Straw } \\
\text { yield } \\
\left(\mathrm{kg} \mathrm{ha}^{-1}\right)\end{array}$ \\
\hline \multicolumn{8}{|l|}{ Phosphorus levels } \\
\hline $\mathrm{P}_{0}$ (Control) & 26.81 & 18.02 & 47.15 & 2.06 & 3.09 & 850 & 2100 \\
\hline $\mathrm{P}_{1}\left(20 \mathrm{~kg} \mathrm{P}_{2} \mathrm{O}_{5} \mathrm{ha}^{-1}\right)$ & 29.22 & 20.97 & 54.58 & 2.74 & 3.65 & 1075 & 2658 \\
\hline $\mathrm{P}_{2}\left(40 \mathrm{~kg} \mathrm{P}_{2} \mathrm{O}_{5} \mathrm{ha}^{-1}\right)$ & 31.51 & 23.02 & 58.92 & 3.11 & 4.06 & 1221 & 2988 \\
\hline $\mathrm{P}_{3}\left(60 \mathrm{~kg} \mathrm{P}_{2} \mathrm{O}_{5} \mathrm{ha}^{-1}\right)$ & 32.00 & 24.17 & 60.12 & 3.22 & 4.20 & 1231 & 3125 \\
\hline $\mathrm{SEm} \pm$ & 0.74 & 0.66 & 1.34 & 0.08 & 0.07 & 28.35 & 64.30 \\
\hline $\mathrm{CD}(\overline{\mathrm{P}}=0.05)$ & 2.13 & 1.91 & 3.87 & 0.23 & 0.21 & 81.86 & 185.68 \\
\hline \multicolumn{8}{|l|}{ Biofertilizers } \\
\hline $\mathrm{B}_{0}($ Control $)$ & 26.33 & 18.43 & 47.38 & 1.99 & 3.26 & 848 & 2123 \\
\hline $\mathrm{B}_{1}(\mathrm{PSB})$ & 29.88 & 20.94 & 55.27 & 2.80 & 3.71 & 1116 & 2740 \\
\hline $\mathrm{B}_{2}$ (Aspergillus awamori) & 30.09 & 22.35 & 56.12 & 2.87 & 3.90 & 1153 & 2867 \\
\hline \multicolumn{8}{|l|}{$\mathrm{B}_{3}(\mathrm{PSB}+$ Aspergillus } \\
\hline awamori) & 33.24 & 24.47 & 62.01 & 3.48 & 4.13 & 1260 & 3140 \\
\hline $\mathrm{SEm} \pm$ & 0.74 & 0.66 & 1.34 & 0.08 & 0.07 & 28.35 & 64.30 \\
\hline $\mathrm{CD}(\overline{\mathrm{P}}=0.05)$ & 2.13 & 1.91 & 3.87 & 0.23 & 0.21 & 81.86 & 185.68 \\
\hline
\end{tabular}

\section{Effect of biofertilizers}

The data of growth attributes (Table 1) revealed that seed inoculation with PSB + Aspergillus awamori significantly increased the total and effective root nodules per plant at flowering stage, plant height, leaf area index and total chlorophyll content, grain yield and straw yield over no inoculation. However, the treatment B1 and B2 were statistically at par. The increase in growth parameters and yield may be due to might be due to the higher phosphatases activity in the rhizosphere and production of organic acids by Aspergillus niger might have solubilized the insoluble and native phosphate and brought into soluble form.

This resulted in increased $\mathrm{P}$ uptake by the crop. Apart from increased enzyme activities, the beneficial effects of Aspergillus niger on plant growth might also include the production of plant growth promoter. Greater phosphatases activity has been directly implicated in the acquisition of more $\mathrm{P}$ by plants (Yadav and Tarafdar, 2010).

The combined inoculation of PSB + Aspergillus awamori to seed are the most efficient inoculation in increasing higher values of growth parameters at almost all phonological stages. Dual inoculation might have contributed something towards enhanced plant growth and increased $\mathrm{N}$ or soluble $\mathrm{P}$. Furthermore, increased population of soil microorganisms might have interacted on more metabolic level i.e. production of Auxin, IAA and Gibberellin which might have incremented into soil environment during growth. The inoculation with PSB + Aspergillus awamori also significantly increased the values of growth parameters as its combination gave synergistic effect. A positive influence of Aspergillus awamori inoculation on plant growth parameter was observed due to higher enzyme activities in 
the rhizosphere and better nutrient availability besides the production of the plant growth regulators by biofertilizers which stimulated plant growth. The production of organic acids such as lactic, glycolic and succinic acids in the soil medium of Aspergillus awamori can solubilize unavailable inorganic phosphates.

Since phosphorus is one of the essential major nutrient and is required in adequate amounts in the available form for the growth and reproduction of plants and is also associated with several vital functions and is responsible for many characteristics of plant growth. The high biomass implies increase in the rate of photosynthesis due to high leaf number and leaf area (Majengo et al., 2011). The photosynthates are transported via phloem and used in grain yield production. The results obtained in the investigation are in line with the findings of Bhatt et al., (2013), Pramanik et al., (2014), Vanita et al., (2014), Tiwari et al., (2015), Rathour et al., (2015), Choudhary et al., (2015).

Based on the results of the experiment, it could be concluded that the application of phosphorus@40 kg ha ${ }^{-1}$ and dual inoculation of biofertilizers (PSB + Aspergillus awamori) had significant effect in improving the growth attributes and yield (grain and straw) in comparison to other treatments of mungbean.

\section{References}

Bhatt, P. K., Patel, P. T., Patel, B. T., Raval, C. H., Vyas, K. G. and Ali, S. 2013. Productivity, quality, nutrient content and soil fertility of summer greengram (Vigna radiata) as influenced by different levels of vermicompost and phosphorus with and without PSB. International Journal of Agricultural Sciences, 9: 659-662.

Choudhary, R., Singh, K., Manohar, R. S., Yadav, A. K., and Sangwan, A.
2015.Response of different sources and levels of phosphorus on yield, nutrient uptake and net returns on mungbean under rainfed condition. Indian Journal of Agriculture Research,35: 263-268.

Escalante E. J. A. S., Barrios A. P., González, R. M. T., Chávez, G. M. C., Barrios, A. M. 2014. Analysis of Cowpea Growth and Production in Maize Trellis with Nitrogen and Phosphorus. International Journal of Agriscience, 4: 102-108.

Giaquinta R. T. and Quebedeaux, B. 1980. Phosphate induced changes in assimilate partitioning in soybean leaves during pod filling. Plant Physiology, 65: 119.

Majengo, C. O., Okalebo, J. R., Lesueur, D., Pypers, P., NG'Etich, W., Mutegi, E., Mburu, M. W. and Musyoki, M. 2011. African Crop Science Society Interaction between nitrogen and phosphorus microbial inoculants on soybean production in Bungoma, Kenya. African Crop Science Conference Proceedings, 10: $121-123$.

Malik, A. M., Saleem, M. F., Ali, A. and Mahmood, I. 2003.Effect of nitrogen and phosphorus application on growth yield and quality of mungbean (Vigna radiate L.).Pak. j. agri. sci., 4: 113-116.

Paul, N. B.; Rewari, R. B.; Sen, A., Sundrao, W. V. B. and Bhatnagar, R. S. 1971.Rhizobial inoculation of pulse crops for better yields. Division of microbiology, New vistas in pulse production, Indian Agriculture Research Institute, New Delhi, pp.47-56.

Pramanik, J. K., Chowdhary, A. K. M. S. H. and Uddin, F. M. J. 2014.Effect of Biofertilizer and Weeding on the Growth Characters and Seed Yield of Summer Mungbean.J. Environ. Sci. \& Natural Resources, 7: 87-92.

Prasad, S. K., Singh, M. K. and Singh, J. 2014. Response of rhizobium inoculation and phosphorus levels on 
mungbean (Vigna radiata L.) under guava-based agri-horti system. The Bioscan, 9: 557-560.

Rathour, D. K., Gupta, A. K., Choudhary, R. R. and Sadhu, A. C. 2015. Effect of Integrated Phosphorus Management on Growth, Yield Attributes and Yield of Summer Green Gram (Vigna radiata L.).The Bioscan, 10: 05-07

Sharma, M.P. and Khurana, A.S. 1997. Biofertilizers, Farmer and parliament. Indian Journal of Agricultural Sciences, 38: 17-18.

Tiwari, S., Kumar, S., Maurya, D. K., Singh, S. K., Verma, P. K. 2015. Effect of Phosphorus levels on Growth, Seed yield, Quality and Nutrient Uptake by
Greengram (Vigna radiate L.). Enviroment\& Ecology, 33: 1731-1733.

Vanitha, M., Radha, S. R. and Vijayakumari, B. 2014. Herbals and biofertilizer as a nutrient supplement for improving biochemical parameters of cluster bean (Cyamopsis tetragonoloba L. Var. PNB). Journal of Natural Production Plant Resources, 4: 29-33.

Yadav, B. K. and Tarafdar, J. C. 2010. Studies on phosphates activity and clusterbean production as influenced by the P mobilizing organism Emmericella rugulosa. Legume Research, 33: 118220.

\section{How to cite this article:}

Ch. Vidhyashree Venkatarao, S.R. Naga, B.L. Yadav, Deepak Kumar Koli and Jagga Rao, I. 2017. Effect of Phosphorus and Biofertilizers on Growth and Yield of Mungbean [Vigna radiata (L.) Wilczek]. Int.J.Curr.Microbiol.App.Sci. 6(7): 3992-3997. doi: https://doi.org/10.20546/ijcmas.2017.607.413 